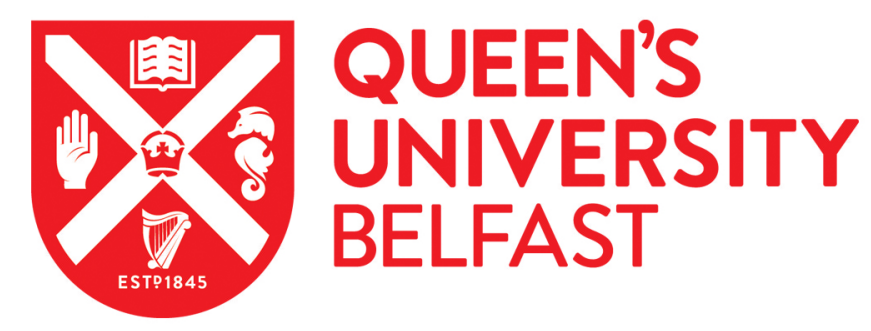

\title{
Strength reduction of till under dynamic pore pressure condition
}

Harley, R., Sivakumar, V., Hughes, D., \& Donohue, S. (2016). Strength reduction of till under dynamic pore pressure condition. Geotechnique Letters, 6(1), 83-88. https://doi.org/10.1680/jgele.15.00156

\author{
Published in: \\ Geotechnique Letters
}

\section{Document Version:}

Peer reviewed version

Queen's University Belfast - Research Portal:

Link to publication record in Queen's University Belfast Research Portal

\section{Publisher rights}

Copyright 2016 @ ICE Publishing, all rights reserved.

This work is made available online in accordance with the publisher's policies.

\section{General rights}

Copyright for the publications made accessible via the Queen's University Belfast Research Portal is retained by the author(s) and / or other copyright owners and it is a condition of accessing these publications that users recognise and abide by the legal requirements associated with these rights.

Take down policy

The Research Portal is Queen's institutional repository that provides access to Queen's research output. Every effort has been made to ensure that content in the Research Portal does not infringe any person's rights, or applicable UK laws. If you discover content in the Research Portal that you believe breaches copyright or violates any law, please contact openaccess@qub.ac.uk. 
The strength reduction of overconsolidated till under static and dynamic pore water pressure conditions

\author{
R Harley, V Sivakumar, D Hughes and S Donohue
}

\begin{abstract}
Cuttings in heavily overconsolidated clays are known to be susceptible to progressive deformation caused by creep and fatigue which usually begins at the toe of the slope. The progressive deformation leads to strength reduction with time at constant stress (or called softening) and could be accelerated by fluctuation of groundwater level associated with more extreme rainfall events predicted through climate change. The purpose of this article is to assess the mechanism of progressive deformation due to creep and fatigue using element testing on samples of till. The samples were subjected to fully drained loading and the deviator stresses were held constant at various percentages of the peak failure stress while the pore water pressure was kept static or dynamic (fluctuating $\pm 5 \mathrm{kPa}$ ) over a period of time. The results have shown that the samples experienced significant deformation even at higher factor of safety (i.e. the failure deviator stress/ deviator stress at which the pore water pressure was fluctuated) under pore water pressure dynamics.
\end{abstract}

Key words: pore water pressure, till and stress path 


\section{INTRODUCTION}

A slope failure of a deep cutting in glacial till at Dromore, along the A1 Belfast-Newry dual carriageway in Northern Ireland was reported by Hughes et.al, 2007. The factor postulated for instigating the slope failures was a reduction in long-term shear strength due to a combination of progressive deformations, strain softening, dissipation of excess pore water pressure generated during initial excavations together with pore water pressure dynamics triggered by weather patterns. Such progressive deformation is generally referred to as "creep and fatigue" (Bjerrum, 1967; Burland et al., 1977; Locat et al., 2011) and this terminology is used in the rest of the paper.

The research reported in this article was based on a more recent, 10 year old cutting also located along the A1 Belfast-Newry dual carriageway. This cutting, located at Loughbrickland, Northern Ireland (Figure 1) is in a similar geological setting to the Dromore cutting, and is one of the deepest cuttings in Northern Ireland at $25 \mathrm{~m}$ high (Figure 1b) and at a slope angle of $26^{\circ}$. The soil profile is composed of a weathered Greywacke (Silurian shale), overlain by a stiff lodgement till with an upper weathered zone (Figure 1b). The site is fully instrumented to monitor pore water pressure dynamics, surface water balance, infiltration and meteorological conditions (Clarke, 2007; Carse, 2014; McLernon, 2014).

The deformation of slopes due to creep and fatigue is likely to be a contributing factor in the time-dependant strength reduction and degradation of slopes. It has long been recognised that, for many soils, the creep can be a significant contributor to the overall behaviour of geotechnical structures (Karim et al., 2011; Yin and Graham, 1999; Kelln et al., 2007). A number of Elastic-Viscoplastic (EVP) models (Kutter and Sathialingam, 1992; Karim et al., 2010; Yin, 2001; Kelln et al., 2008) have been developed to predict the long-term performance of these structures, including cuttings. A reliable estimation of geotechnical parameters is therefore necessary in order to accurately predict the performance of such structures. This paper therefore reports the investigations carried out to understand this time-dependent behaviour of overconsolidated till.

\section{LABORATORY INVESTIGATION}

The direction of principal stresses changes behind the slope. At the crest, the vertical stress is higher than the lateral (i.e. compression) and the reverse (extension) prevails at the toe. In the present investigation the condition of the soil behind slope at the crest was examined. The investigation would ideally have been conducted on undisturbed soil samples of tills. However obtaining undisturbed $50 \mathrm{~mm}$ diameter triaxial samples of till is very problematic 
due to the high gravel contents (Carse, 2014). As the intention of the research was to delineate the concept of deformation of slopes due to creep and fatigue it was deemed that testing the response of reconstituted samples of till (without large gravel particles) would be satisfactory within the remit of the research. Disturbed samples were collected from varying depths and particles more than $5 \mathrm{~mm}$ were removed. The remaining material was oven dried for 24 hours at $85^{\circ} \mathrm{C}$ and finally crushed using a pestle and mortar to powder form. Particle size distribution (PSD) was carried out on the bulk and reconstituted materials in accordance with BS EN 1997-2:2007 and the relevant information is shown in Figure 2. The material from the bulk sample was identified as slightly gravelly sandy silty CLAY with a liquid limit (LL) of $38 \%$ and a plastic limit (PL) of $17 \%$.

Bassed on the PSD, ignoring the two odd cases marked as S-1 and S-2 on Figure 2), it appears that a maximum of about $17 \%$ of the larger gravel particles by dry mass have been removed to form the reconstituted samples. It is therefore acceptable to assume that the clay removed from the site was matrix dominated. In order to further give assurance on the comparability of the reconstituted with in-situ samples, the ultimate state (or critical state) of the till from the original investigations carried out on slightly disturbed samples $(105 \mathrm{~mm}$ diameter) during the excavation at Loughbrickland site is compared with the same obtained on reconstituted samples (discussed in details later) in Figure 3 and the agreement between the observations is good. Despite this, it is recognised that the reconstituted samples do not fully represent the in-situ conditions for two reasons: (a) anisotropy induced by the deposition process, and (b) one-dimensional loading history imposed on the deposit for a long period, although, as discussed later, in the present investigation this is addressed to some extent by producing samples under one-dimensional loading conditions.

Tests were carried out on heavily overconsolidated $(50 \mathrm{~mm}$ diameter, $100 \mathrm{~mm}$ high) reconstituted samples. These samples were prepared by consolidating soil slurry mixed at 1.5 times the liquid limit (LL). The slurry was thoroughly mixed and was allowed to soak for 24 hours before being consolidated in a 1D consolidation cell under a vertical pressure of $800 \mathrm{kPa}$ to replicate the possible past stress history (Gregory and Bell 1991; Carse, 2014). The one-dimensionally consolidated samples were then tested using stress path apparatus. Side drains were used to accelerate the drainage process (Sivakumar et al., 2010). The radial and axial strains were measured locally by attaching a radial strain belt and inclinometers respectively.

The samples were saturated using a standard procedure and B value of at least 0.95 was obtained. Although the samples were previously consolidated in a one-dimensional cylinder 
to $800 \mathrm{kPa}$, it was likely that the stress distribution along the sample may not be uniform due

Three series of tests were carried out: In testing series (A), three samples were tested in order to establish the peak failure envelope and the critical state line. The samples consolidated to effective consolidation pressures of $25 \mathrm{kPa}, 50 \mathrm{kPa}$ and $100 \mathrm{kPa}$ were subjected to fully drained loading using the stress control method at a rate of $1 \mathrm{kPa} / \mathrm{h}$. This rate was established based on the consolidation characteristics of the sample and validated using some preliminary testing. It was the intention of the research to establish the peak failure envelope and the critical (ultimate) state line. However the latter cannot be established using stress control loading, therefore the loading method was changed to strain control at a rate of $0.001 \mathrm{~mm} / \mathrm{h}$ when the sample approached closer to the peak state.

In the second testing series $(B)$, the investigation focussed on the response of the sample under a constant deviator stress while holding static pore water pressure conditions. The samples were initially consolidated to $800 \mathrm{kPa}$ of effective stress and unloaded to $50 \mathrm{kPa}$. The deviator stress was then applied on the sample using the stress control method and upon reaching a required deviator stress $(90 \%, 80 \%$ and $70 \%$ of the anticipated peak deviator stress) the loading was maintained constant for a prolonged period of time (4-5 weeks). When appropriate the samples were subsequently subjected to further loading to critical state using the strain control method.

In the testing series $(C)$, the deviator stress was taken to a target value (as in the case of Test series $\mathrm{B}$ ) and the pore water pressure was cycled by $\pm 5 \mathrm{kPa}$ in a ramp fashion at a rate of $0.04 \mathrm{kPa}$ per hour. The samples were subsequently taken to critical state.

\section{DISCUSSION ON RESULTS}

Eight samples were tested in total and they were all prepared in the same fashion. The average initial void ratio of the samples was approximately 0.50 with a variation of \pm 0.015 . 
This is considered to be repeatable given the fact that material contained $50 \%$ granular content with some marginal variations.

Figure 4 shows the stress-strain behaviour of samples subjected to monotonic loading (continuous loading without any rest periods) until critical state. As discussed above, the loading was initially stress controlled and subsequently strain controlled, and the changeover between these loading mechanisms is indicated by circular data points in Figure 4a. In order to ensure good data quality, one of the tests carried out as part of testing series (B) is also included. The later part of the stress-strain curve of this test is removed to avoid confusion (this will be discussed later). There is good consistency between the stress-strain curves, which gives further credence to the sampling method adopted in this research. The sample consolidated to $25 \mathrm{kPa}$ reached peak state at an axial strain of $1.5 \%$ and critical state at approximately $3.2 \%$. At this stage, multiple visible shear planes had formed. The sample consolidated to $50 \mathrm{kPa}$ reached peak state and critical state in the same order of axial strains and eventually failed on shear planes. However no significant sign of peak state was observed in the case of the sample consolidated to $100 \mathrm{kPa}$. In all three cases, the samples initially contracted, and subsequently dilated as they approached the peak and critical states (Figure 4b). The peak angle of internal friction of the reconstituted material is approximately $32^{\circ}$ and the cohesion is about $7 \mathrm{kPa}$ (Figure $4 \mathrm{c}$ ). The angle of internal friction at critical state is approximately $33^{\circ}$. The later part of this article will discuss if this cohesion is permanent or will erode away if the sample experiences creep.

In test series (B), the samples were loaded to $90 \%$ and $80 \%$ (and a repeat test at $90 \%$ ) of the peak deviator stress. Figure $5 \mathrm{a}$ and $\mathrm{b}$ shows the deviator stress and volumetric strain plotted against axial strain and Figure $5 \mathrm{c}$ shows the accumulated shear strain plotted against time (log scale). The test carried out under monotonic loading conditions is also included in this figure for comparison purposes. The consistency of the data leading up to the target deviator stress is remarkably similar. Upon reaching the target deviator stress, the control programme was used to hold the axial load on the sample constant rather than the deviator stress. Since the samples were deforming under a maintained load, the area of the sample gradually changed and therefore the deviator stress reduced slightly. Nevertheless the samples exhibited a continuous deformation under maintained loading conditions and this deformation is regarded as creep. The samples eventually reached the critical state and began to fail on the shear plane. The deviator stress at which the samples approached to critical state is much similar to that of the sample monotonically loaded. The time-dependent 
response of the sample is shown in Figure $5 c$ where the acute development of accumulative shear strain occurred closer to the critical state.

The most intriguing observation from the investigation is from the sample subjected to $80 \%$ of the peak deviator stress and then held at a constant axial load for 4 weeks. The sample underwent creep at the same rate as that of other samples at the beginning of the maintained loading conditions, but exhibited a slowdown as the resting period continued. In order to see if the shear strain that the sample experienced had caused any strength reduction the sample was subsequently loaded to critical state using the strain control method. It is remarkable that the sample initially reached a peak and eventually approached critical state. The peak deviator stress identified from this test is significantly smaller than that identified from the monotonic loading test, implying that the shear strain that the sample experienced during maintained loading conditions had caused some noticeable softening, implying that the cohesion that the sample inherited from the original loading is not permanent and can be eroded by long-term creep as suggested by Lacerda (1976). The approximate reduction in cohesion is $3 \mathrm{kPa}$, which is significant in terms of stability of slopes cut at critical angles.

The deformation due to creep and fatigue and consequently the reduction in cohesion can be accelerated by pore water pressure dynamics due to environmental changes. Figure 6 shows the stress-strain curves and stress paths of two samples subjected to pore water pressure dynamics in which the pore water pressure was cycled by $\pm 5 \mathrm{kPa}$, after reaching a target deviator stress of $80 \%$ and $70 \%$. Also included in this figure is the stress-strain curve for monotonic loading for comparison. In the case of $80 \%$ target deviator stress, the sample continued to deform under dynamic pore water pressure conditions (Figure 6c) and the rate of accumulative shear strain was much faster than that of the sample tested without any pore water pressure dynamics. It implies that pore water pressure dynamics can play a key role in the creep response and consequently it contributed to rapid reduction in the strength. However when the pore water pressure was cycled at a maintained deviator stress of $70 \%$ of the peak, the rate of creep (in the form of accumulative shear strain) was significantly reduced and it became insignificant after 10 weeks of pore water pressure dynamics. At this stage the sample was monotonically loaded to failure and the observation seems to suggest that there was no reduction in cohesion due to the small amount of creep that took place during the resting period. 


\section{CONCLUSION}

The aspect of deformation due to creep and fatigue was examined using a series of stress path tests carried out on reconstituted tills. The samples were loaded monotonically and in some cases the deviator stress was maintained constant at a given percentage of peak failure stress. When subjected to $90 \%$ of the peak failure stress, the sample continued to experience shear strain however when this percentage was reduced to $80 \%$, the accumulative shear was less, though the subsequent monotonic loading has shown a clear indication of reduced cohesion. The pore water pressure dynamics aggravated the accumulation of shear strain due to creep and fatigue. Under dynamic pore water pressure conditions, the sample subjected to $80 \%$ of the peak failure stress experienced significantly high shear strain and reached critical state. However the accumulated shear strain was less significant and the reduction in cohesion was insignificant when the dynamic pore water pressure condition was imposed on the sample at $70 \%$ of the peak failure stress.

\section{REFERENCES}

Bjerrum, L. (1967) Engineering geology of Norwegian normally consolidated marine clays as related to settlements of buildings Geotechnique, 17(2): 81-118.

Burland, J.B., Longworth, T.I., Moore, J.F.A. (1977). A study of ground movement and progressive failure caused by a deep excavation in Oxford Clay. Geotechnique 27 (4), pp. 557-591.

Carse, L. (2014) The geomechanical response of cut slopes in glacial till to climateically driven porepressure cycling and hydrogeolgoy. PhD Thesis, Queen's University Belfast, United Kingdom.

Clarke, G.R.T. (2007) The impact of climate on the hydrogeology and stability of a large excavation in glacial till. PhD Thesis, Queen's University Belfast, United Kingdom.

Gregory, B.J. and Bell, A.L. (1991) Geotechnical properties of Quaternary deposits in the Belfast area. Geological Society Engineering Geology Special Publication, (7), 219-228.

Hughes, D.A.B., Sivakumar, V., Glynn, D. and Clarke, G.R.T. (2007) A case study: delayed failure of a deep cutting in lodgement till. Geotechnical Engineering, 160(GE4), 193-202.

Karim, M.R., Gnanendran, C.T., Lo, S.-C.R., and Mak, J. (2010) Predicting the long-term performance of a wide embankment on soft soil using an elastic-visco-plastic model. Canadian Geotechnical Journal, 47: 244-257.

Karim, M. R., G. Manivannan, et al. (2011) Predicting the long-term performance of age ogridreinforced embankment on soft soil using two-dimensional finite element analysis. Canadian Geotechnical Journal 48(5): 741-753.

Kelln, C. (2007). An elastic-viscoplastic constitutive model for soil. PhD Thesis, Queen's University Belfast, United Kingdom.

Kelln, C., Sharma, J., Hughes, D., and Graham, J. (2008) Finite element analysis of an embankment on a soft estuarine deposit using and elastic-viscoplastic soil model. Canadian Geotechnical Journal, 46: 357-368. 
Kutter, B.L., and Sathialingam, N. (1992) Elastic-viscoplastic modelling of the rate-dependent behaviour of clays. Geotechnique, 42: 427-441.

Lacerda, W.A. (1976) Stress Relaxation and Creep Effects in Clays. PhD Thesis, University of California, Berkeley.

Leroueil, S. (2001) Natural slopes and cuts: movement and failure mechanisms. Geotechnique 51 (3), pp. 197-243.

Locat, A., Leroueil, S., Bernander, S., Demers, D., Jostad, H.P., Ouehb, L. (2011) Progressive failures in eastern Canadian and Scandinavian senstivie clays. Canadian Geotechnical Journal, 2011, 48 (11), pp. 1696-1712.

McLernon, M. (2014) The influence of climate variability on pore water pressure dynamics and slope stability within glacial till drumlins in Northern Ireland. PhD Thesis, Queen's University Belfast, United Kingdom.

Murphy, J.M. (2009) UK Climate Projections Science Report: Climate change projections, Exeter: Met Office Hadley Centre, Exeter.

Sivakumar, V., Mackinnon, P., Zaini, J., Cairns, P. (2010) Effectiveness of filters in reducing consolidation time in routine laboratory testing. Geotechnique, 60: 949-96.

Yin, J.-H., and Graham, J. (1999) Elastic viscoplastic modelling of time-dependent stress-strain behaviour of soils Canadian Geotechnical Journal, 36(4): 736-745.

Yin, J.H. (2001) A refined elastic visco-plastic model for clayey soils. Geotechnical Engineering Journal 32(1): 23-31. 
Table 1. Summary of compression loading tests

\begin{tabular}{|c|c|c|c|c|c|c|c|}
\cline { 2 - 8 } \multicolumn{1}{c|}{} & \multicolumn{3}{c|}{ Initial Condition } & \multicolumn{4}{c|}{ Loading } \\
\hline $\begin{array}{c}\text { Testing } \\
\text { Series }\end{array}$ & $\begin{array}{c}\text { Cell Pressure } \\
(\mathrm{kPa})\end{array}$ & $\begin{array}{c}\text { PWP } \\
(\mathrm{kPa})\end{array}$ & $\begin{array}{c}\text { Drainage } \\
(\mathrm{Y} / \mathrm{N})\end{array}$ & $\begin{array}{c}\text { Stress Control } \\
\text { Loading } \\
(\mathrm{kPa} / \mathrm{hr})\end{array}$ & $\begin{array}{c}\text { Strain Control } \\
\text { Loading } \\
(\mathrm{mm} / \mathrm{hr})\end{array}$ & $\begin{array}{c}\text { Peak Stress } \\
(\mathrm{kPa})\end{array}$ & $\begin{array}{c}\text { PWP } \\
(\mathrm{kPa})\end{array}$ \\
\hline A & 325 & 300 & $\mathrm{Y}$ & 1 & 0.001 & $106(100 \%)$ & - \\
\hline A & 350 & 300 & $\mathrm{Y}$ & 1 & 0.001 & $190(100 \%)$ & - \\
\hline A & 400 & 300 & Y & 1 & - & $282(100 \%)$ & - \\
\hline B & 350 & 300 & Y & 1 & - & $173(90 \%)$ & - \\
\hline B & 350 & 300 & $Y$ & 1 & - & $173(90 \%)$ & - \\
\hline B & 350 & 300 & Y & 1 & 0.001 & $158(80 \%)$ & - \\
\hline C & 350 & 300 & Y & 1 & - & $158(80 \%)$ & \pm 5 \\
\hline C & 350 & 300 & Y & 1 & 0.001 & $138(70 \%)$ & \pm 5 \\
\hline
\end{tabular}



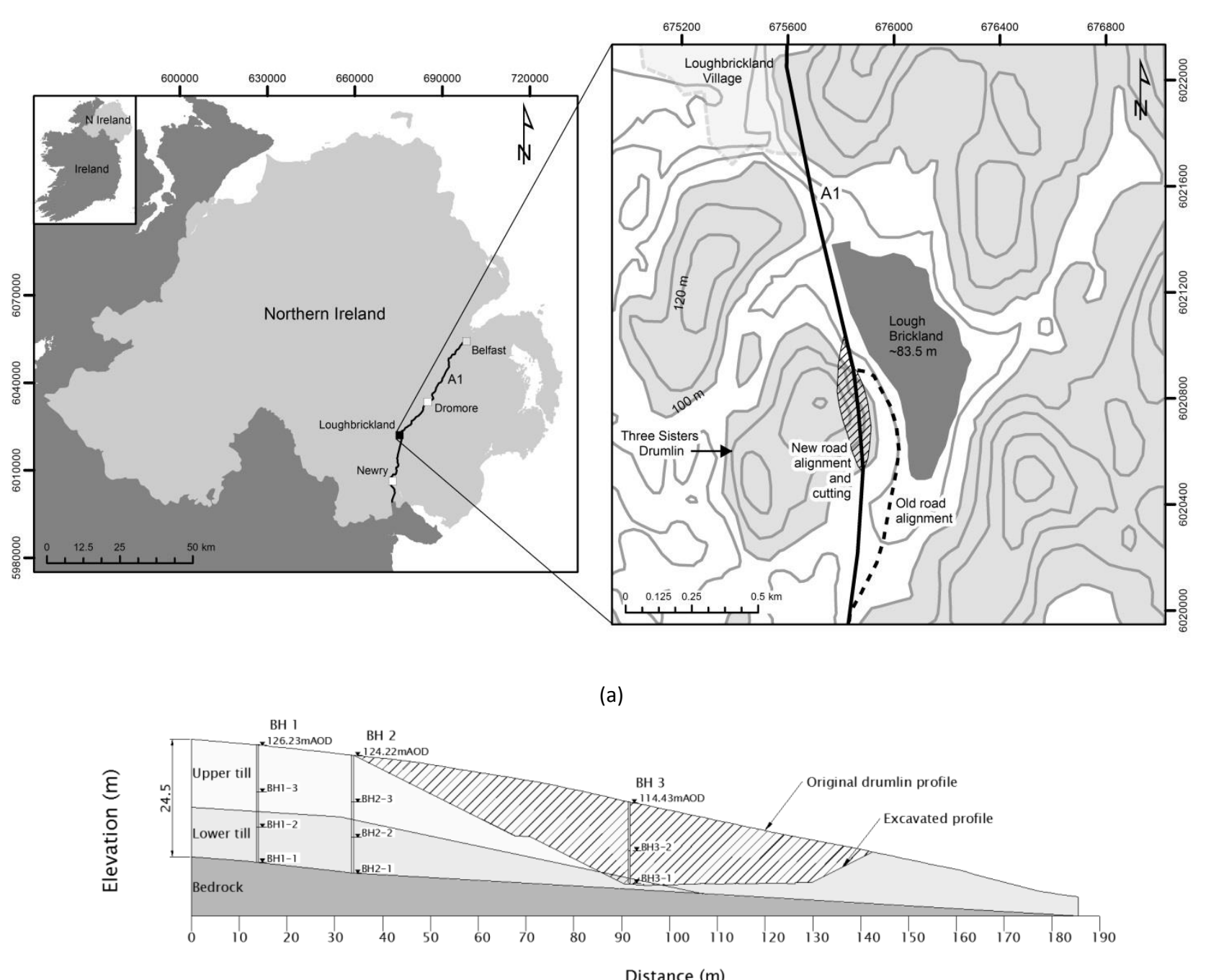

(b)

Figure 1. Location map (grid in ETRS 1989 UTM Zone_29N): (a) A1 Carriageway: Belfast to Dublin Euroroute 1 and contour map of drumlin landscape surrounding 'The Three Sisters' drumlin showing the new horizontal alignment of the dual carriageway, (b) Cross-section of Loughbrickland cutting. 
Figure

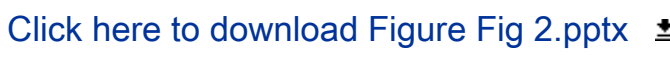

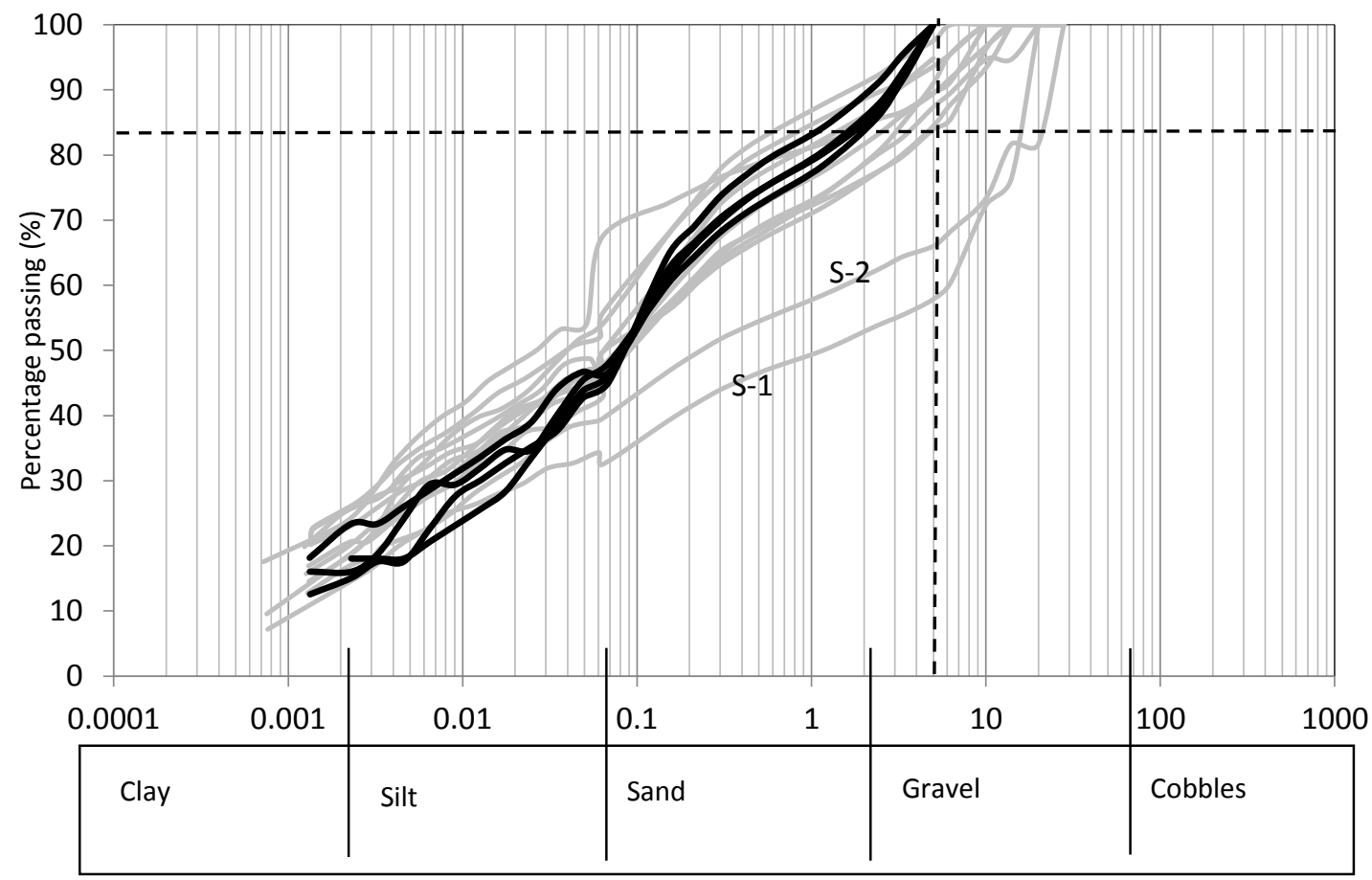

Particle size $(\mathrm{mm})$

Figure 2. Particle Size Distribution of reconstituted samples (black) and bulk samples (grey). 


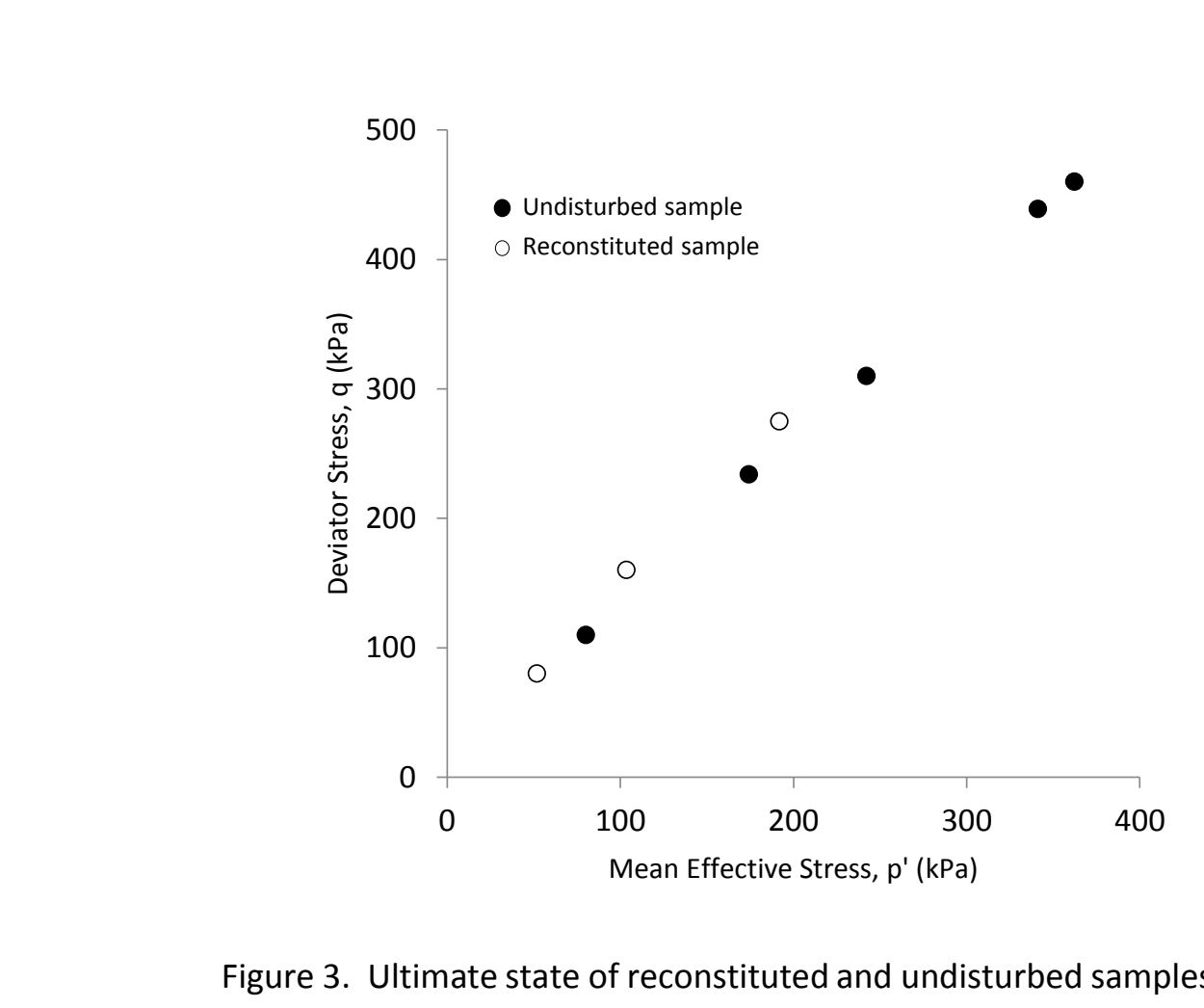

Figure 3. Ultimate state of reconstituted and undisturbed samples 


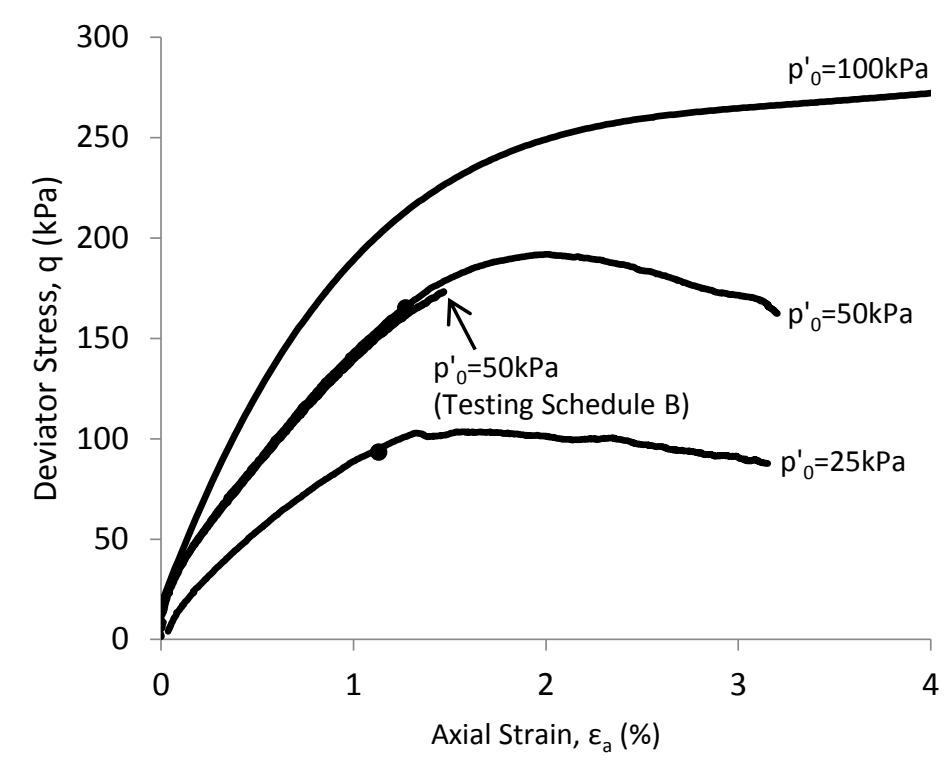

(a) Deviator stress vs axial strain

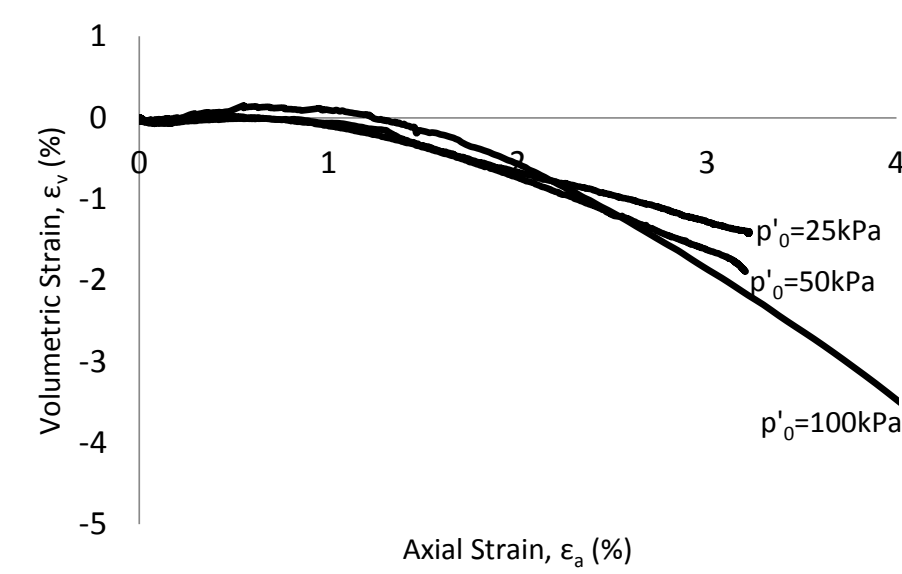

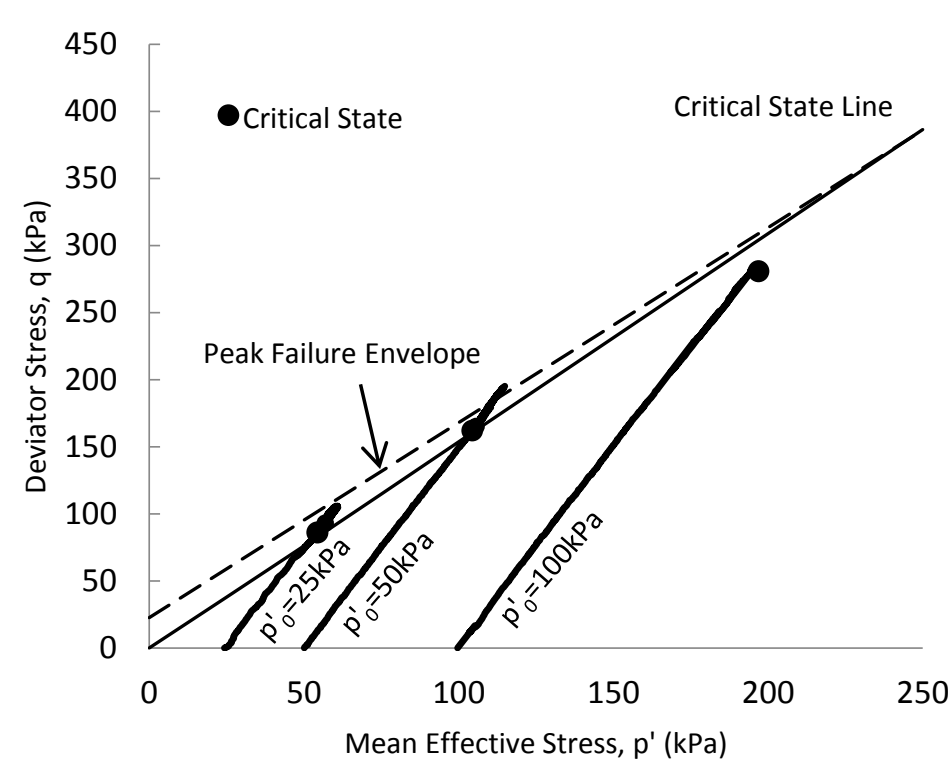

(c) Deviator stress vs mean effective stress

(b) Volumetric strain vs axial strain

Figure 4. Stress strain behaviour and failure envelope under monotonic loading. 

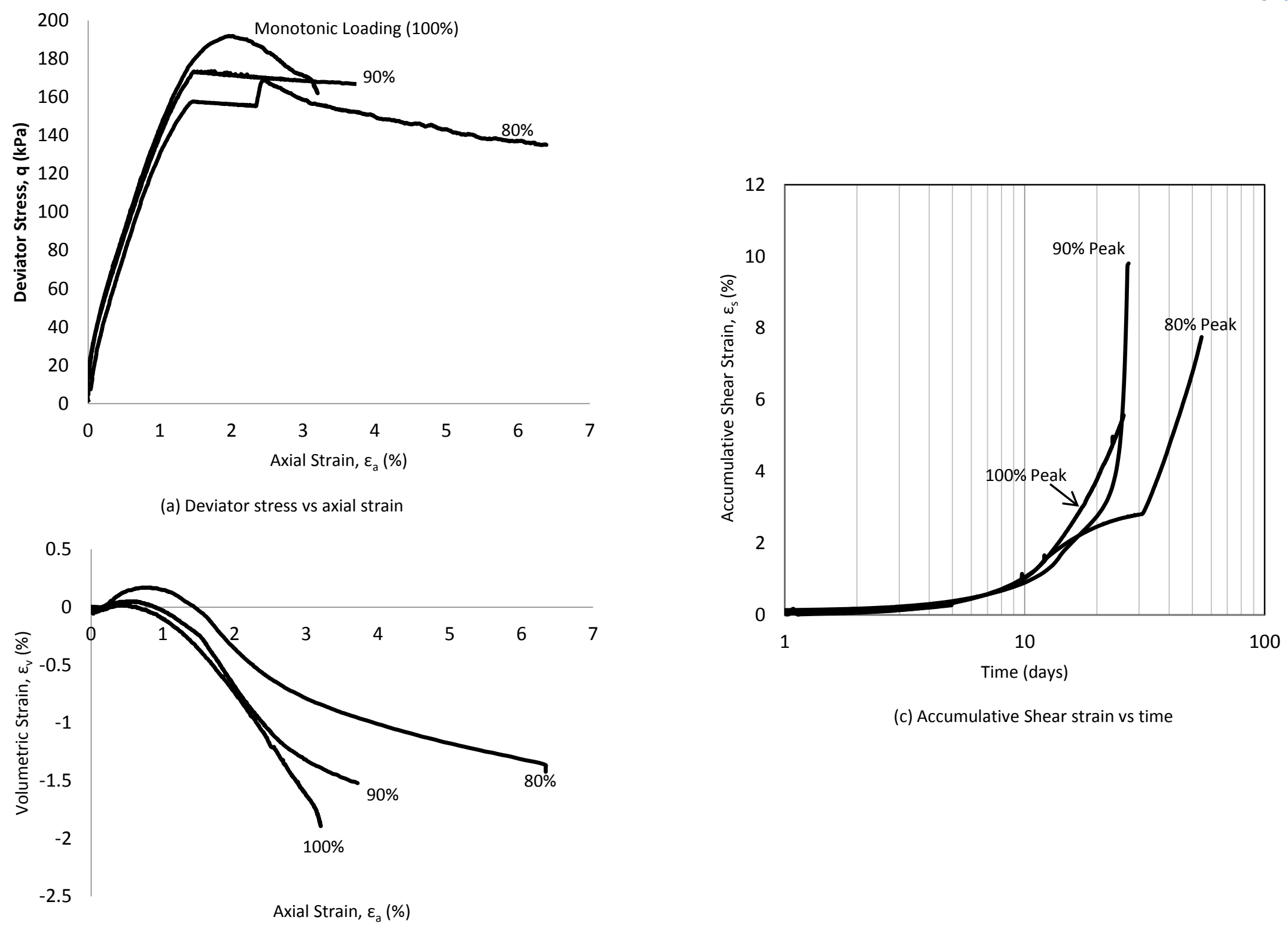

(c) Accumulative Shear strain vs time

(b) Volumetric strain vs axial strain

Figure 5. Testing Schedule (B): Stress strain behaviour and shear strains developed under constant deviator stresses and static pore water pressure conditions. 


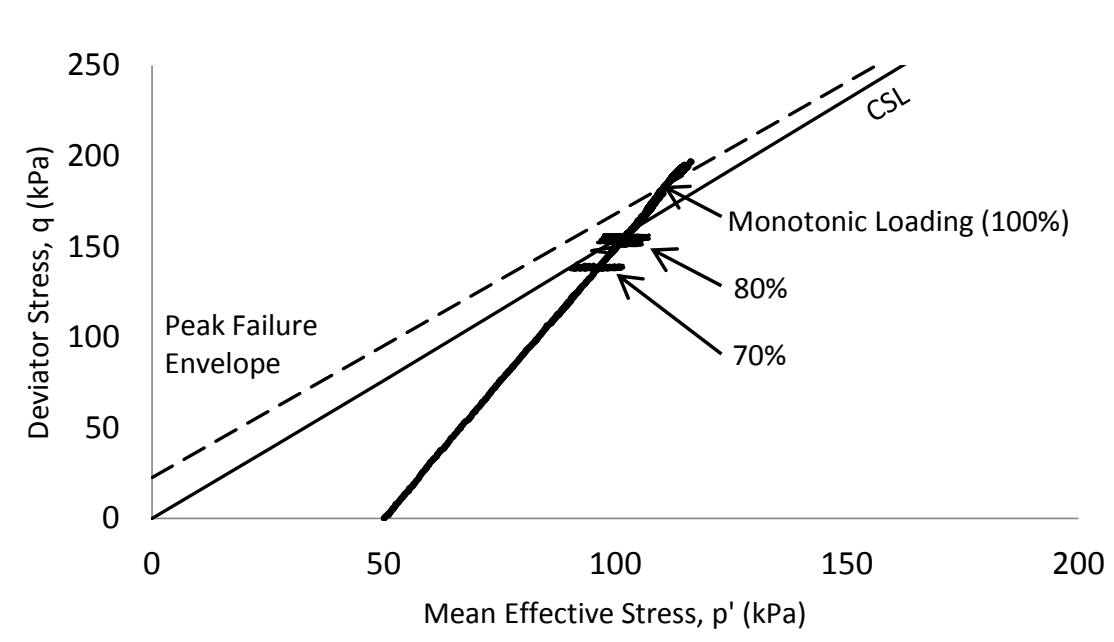

(a) Deviator stress vs mean effective stress

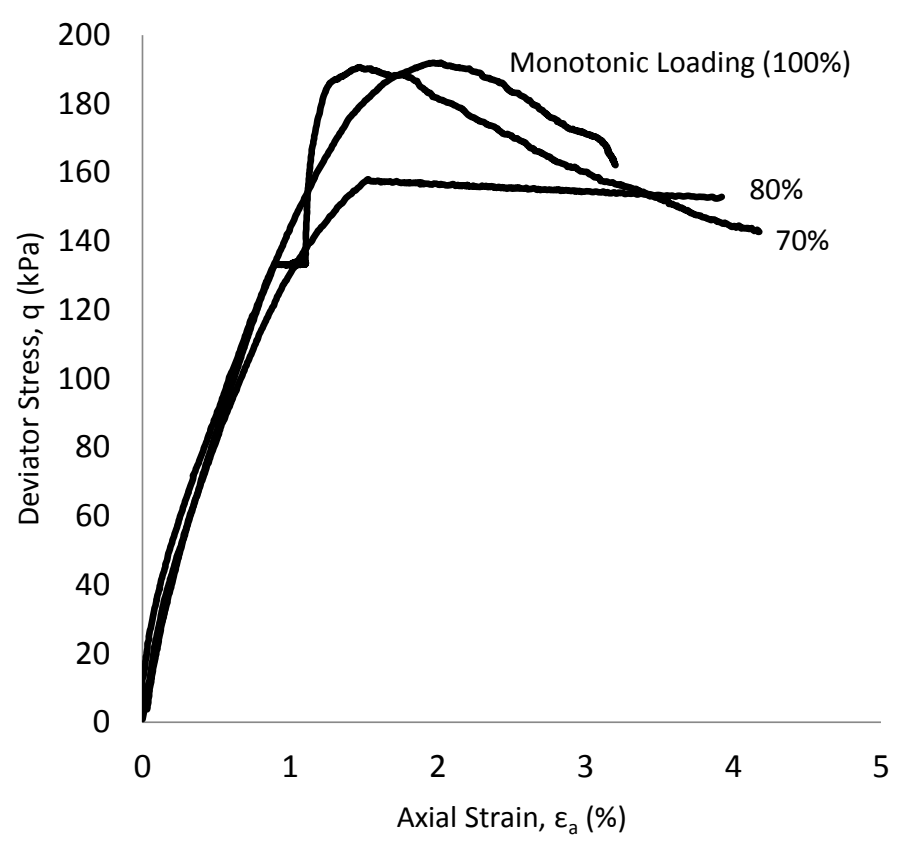

(b) Deviator stress vs axial strain

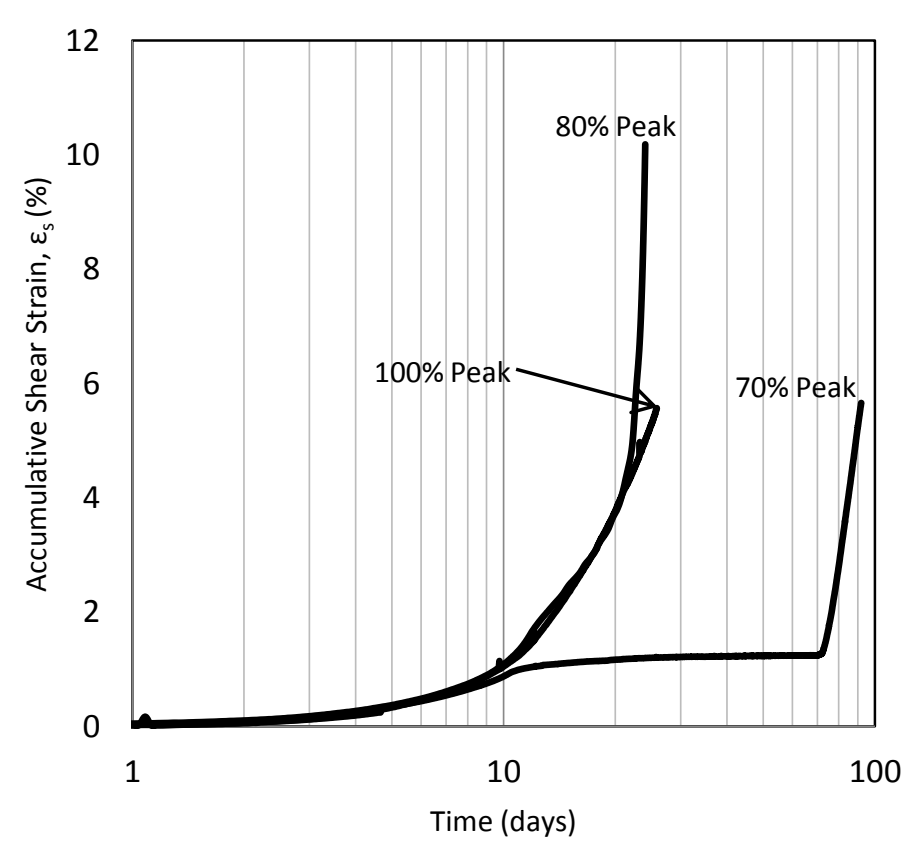

(c) Accumulative Shear strain vs time

Figure 6. Testing Schedule (C): Stress strain behaviour and shear strains developed under constant deviator stresses, and dynamic pore water pressure conditions, $\Delta \mathrm{u}= \pm 5 \mathrm{kPa}$. 